\title{
Factors Impacting Conversations with Friends and Family about Living Kidney Donation
}

\begin{abstract}
Introduction

Living donor kidney transplantation is the optimal modality of renal replacement therapy for advanced kidney disease. It is associated with superior recipient and graft survival, better quality of life and self-reported health status compared to dialysis. Living kidney donation occurs less frequently in members of Black, Asian and Minority Ethnic (BAME) communities in Western countries. This scoping review explores the factors affecting the ability of patients (and health professionals) to initiate conversations about living kidney donation with family and friends, with a focus on BAME population groups.
\end{abstract}

\section{Methods}

208 published articles were identified from online databases using keywords: 'barriers', 'decision making', 'living donor', and 'kidney transplantation'. Studies limited to donors or involving paediatric recipients were excluded,

\section{Results}

There were 25 studies that met the inclusion criteria. Of these, 21 studies included BAME communities. Participants of South Asian ethnicity were underrepresented. Key themes were; 1 ) lack of knowledge 2) risk perception 3) fear of financial burden on donors 4) guilt 5) religious and cultural influences and 6) mistrust of the medical establishment. There were noticeable differences by ethnicity, in level of knowledge, risk perception and fear of financial burden. Religious/cultural reservations and medical mistrust were only reported in people from BAME populations. Two studies explored health professionals' views.

\section{Discussion}

This literature review has identified different barriers to the pursuit of living kidney donation, some of which are linked to ethnicity. This study informs the development of a patient decision aid to support people to have conversations with potential donors, with particular focus on South Asian groups, the second largest ethnic group in the UK.

Key words:

Living kidney donation, chronic kidney disease, kidney failure, kidney transplant, ethnicity, Decision making.

\author{
Ahmed Ahmed ${ }^{1,2}$, Anna \\ Winterbottom $^{1,2}$, John \\ Stoves $^{2,3}$, Shenaz Ahmed ${ }^{1,2}$, \\ Sunil Daga ${ }^{1,2}$
}

1 Renal Department, St. James's University Hospital, Leeds UK; 2 Leeds Institute of Health Sciences, University of Leeds, Leeds UK; 3 Renal Department, St Luke's Hospital, Bradford UK

Ahmed.ahmed30@nhs.net

Cite as: Ahmed, A., Winterbottom, A., Stoves, J., Ahmed, S., Daga, S. (2021) Factors impacting conversations with friends and family about living kidney donation. The Physician vol 7: Issue 1: 1-8 ePub 26.02.2021 DOI: https://doi.org/10.38192/1.7.1.3

Article Information

Submitted 15.02.2021

Revised 26.02.2021

ePub 26.02.2021

ISSN 2732-513X (Print) ISSN 2732 - 5148 (Online) 


\section{Introduction}

Living donor kidney transplantation (LDKT) is advocated as the optimal treatment for people with advanced kidney disease offering improved graft and patient survival ${ }^{(1)}$, patient reported quality of life and morbidity profile following transplantation $(2,3)$. Despite this, LDKT is only performed for $35 \%$ of people with advanced kidney disease in the United Kingdom with a notable ethnic disparity. Members of Black and minority ethnic (BAME) communities constitute approximately $14 \%$ of the general population in the United Kingdom but represent a third of people on the national kidney transplant waiting list ${ }^{(4,5)}$. Only $14 \%$ of people with advanced kidney disease (AKD) from the BAME communities are recipients of LDKT ${ }^{(4)}$. This may be in part due to increased prevalence of chronic illnesses such as diabetes mellitus and hypertension which predispose people to develop advanced kidney disease ${ }^{(6)}$.

Decision making about living kidney donation is a complex process; healthcare professionals convey information to people with kidney disease but to ensure there is no perception of coercion by the clinician, they rely on their patients discussing donation with their friends and family members.

Multiple factors are known to be associated with the uncertainty surrounding LDKT in the Western countries, where national deceased donor programs are established. A UK based multi-centre questionnaire study ${ }^{(7)}$ found that older patients, those from a BAME background, and people of non-Christian religions demonstrated greater uncertainty about positive psychosocial statements related to LDKT. Similarly, certain patients' demographics including ethnicity, age, car and home ownership, marital status and education level were associated with the likelihood of having a living donor transplant ${ }^{(8)}$. Gender disparity in living kidney donation was observed in previous studies with females more likely to be donors than recipients ${ }^{(9)}$.
This review explores the different modifiable factors affecting patients' decision making in initiating conversations about living kidney donation with their potential donors. We aim to explore current literature from the perspectives of patients and their healthcare professionals. This review will guide the development of an intervention to improve patients' ability to initiate conversations around living kidney donation with families and friends with a focus on BAME communities.

\section{Methods}

A survey of primary empirical research employing a rapid review method ${ }^{(10)}$. The keywords included in the search strategy were: "Kidney transplantation", "living donor", Barriers", "Decision making" and "recipients", with reference to the review aims. Articles were identified from: electronic databases Medline and PubMed (01/01/1990-30/11/2020); hand-searching key journals; complete search of reference lists of all articles included in this and prior reviews; reference list of a relevant unpublished doctoral thesis; key authors contacted to request articles; author search in Google Scholar.

\section{Inclusion and exclusion criteria}

Studies included people with AKD, those receiving dialysis, recipients of kidney transplants from deceased or living donors and studies targeting health professionals involved in decision making around LDKT including doctors, transplants co-ordinators and nurses. Studies were excluded if they targeted only living donors, paediatric recipients and abstracts for conference proposes. Two hundred and eight articles were identified and 25 met the inclusion criteria and were included in the review.

Relevant information extracted from the studies in this review included: Study location, year of publication, methods, sample size, characteristics of the participants and the themes included in each study identifying barriers to patients' decision making in initiating discussions about Living kidney donation. Data was recorded in an excel sheet to facilitate categorisation and analysis. 


\section{Results}

Frequently reported themes are summarised according to their prevalence among ethnic groups in Figure (1). Study characteristics are summarised in Tables $1,2,3$ by data collection method.

Figure (1): Barriers to LDKT among ethnic groups

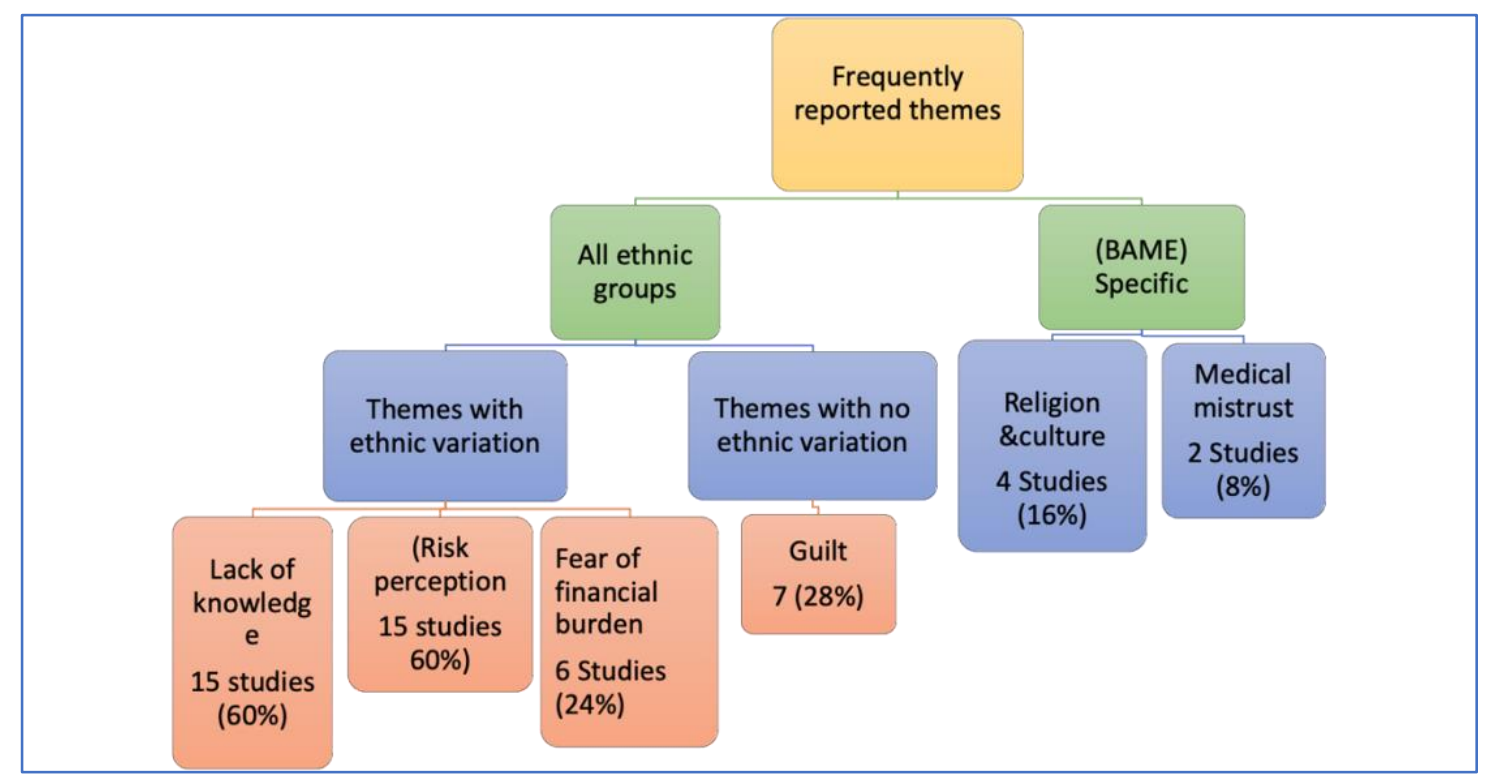

Table (1): Questionnaires/Surveys studies Click link to view

\begin{tabular}{|c|c|c|c|c|c|c|c|c|c|}
\hline $\begin{array}{l}\text { Study } \\
\text { number }\end{array}$ & Author & Title; DOI & Year published & Location & Study design & $\begin{array}{l}\text { Participant's } \\
\text { characteristics }\end{array}$ & Ethnicity & $\begin{array}{l}\text { Sample } \\
\text { size }\end{array}$ & Summary of findings \\
\hline 1 & Burroughs et al & $\begin{array}{l}\text { One organ donation, three perspectives: } \\
\text { experiences of donors, recipients, and } \\
\text { third parties with living kidney donation; } \\
\text { DOI: } \\
\text { 10.7182/prtr.13.2.71t8xj210118m×25 }\end{array}$ & 2003 & USA & Surveys & $\begin{array}{l}\text { Donors (174), } \\
\text { People with } \\
\text { AKD (174) and } \\
\text { third-party } \\
\text { family/friend } \\
\text { (174) }\end{array}$ & $\begin{array}{l}\text {, } 95 \% \text { white }-3 \% \text { African } \\
\text { hAmerican - } 1 \% \text { Asian and } \\
\text { d1\% Hispanics }\end{array}$ & $\begin{array}{l}n 522 \\
d\end{array}$ & $\begin{array}{l}\text { Recipients overestimated how difficult and painful the surgery } \\
\text { and recovery were for donors } \\
\text { Themes: Risk perception }\end{array}$ \\
\hline 2 & Kranenburg et al & $\begin{array}{l}\text { Post-mortal or living related donor } \\
\text { preferences of kidney patients } \\
\text { DOI: } 10.1111 / \mathrm{j} .1432-2277.2005 .00081 . x\end{array}$ & 2005 & Spain & $\begin{array}{l}\text { Questionnaires } \\
\& \quad \text { semi- } \\
\text { structured } \\
\text { interviews }\end{array}$ & $\begin{array}{l}\text { People with } \\
\text { i-AKD and on the } \\
\text { waiting list. } \\
\text { Ethnicity not }\end{array}$ & & 61 & $\begin{array}{l}\text { Main motivation to choose living kidney donation was the } \\
\text { better quality of the living kidney. Main motivation for } \\
\text { choosing post-mortal kidney was fear of burdening a loved one } \\
\text { Themes: risk perception }\end{array}$ \\
\hline 3 & Lunsford et al & $\begin{array}{l}\text { Racial differences in coping with the need } \\
\text { for kidney transplantation and willingness } \\
\text { to ask for live organ donation } \\
\text { DOI: } 10.1053 / \text { j.ajkd.2005.10.018. }\end{array}$ & & USA & Questionnaires & $\begin{array}{l}\text { People with } \\
\text { AKD }\end{array}$ & h61\% African Americans & 333 & $\begin{array}{l}\text { African Americans are more likely to have different perception } \\
\text { of the need for Tx and maladaptive coping mechanisms } \\
\text { Themes: Risk perception }\end{array}$ \\
\hline 4 & Waterman et al & $\begin{array}{l}\text { Why African- Americans are not pursuing } \\
\text { living kidney donation. } \\
\text { DOI:10.1097/00007890-2006607152- } \\
00649\end{array}$ & g2006 & USA & Survey & $\begin{array}{l}\text { People with } \\
\text { AKD and on } \\
\text { Dialysis }\end{array}$ & $\begin{array}{l}\text { h67\% African Americans and } \\
\text { n33\% Caucasian Americans }\end{array}$ & $d 479$ & $\begin{array}{l}\text { African Americans had lower levels of knowledge, more } \\
\text { concerns about the surgery, more fear of transplant failure and } \\
\text { being rejected from potential donors if they refused than } \\
\text { Caucasian Americans. African Americans believe rich/White } \\
\text { patients are treated better by health services } \\
\text { Themes: lack of knowledge, risk perception, guilt and medical } \\
\text { mistrust }\end{array}$ \\
\hline$\overline{5}$ & Zimmerman et al & $\begin{array}{l}\text { The influence of socio-demographic } \\
\text { factors, treatment perceptions and } \\
\text { attitudes to living donation on willingness } \\
\text { to consider living kidney donor among } \\
\text { kidney transplant candidates } \\
\text { DOI } 10.1093 / \mathrm{ndt} / \mathrm{gfl} 218\end{array}$ & & Canada & Survey & $\begin{array}{l}\text { People with } \\
\text { AKD and on the } \\
\text { waiting list. }\end{array}$ & $\begin{array}{l}\text { 61\% Caucasians, other } \\
\text { eethnicities non-specified }\end{array}$ & $r 146$ & $\begin{array}{l}\text { Willingness to consider Living kidney donation was } \\
\text { independently associated with a lower perceived risk of } \\
\text { perioperative complications to the donor (adjusted OR } 3.59 \text {, } \\
\text { P1/40.02), the perception that the recipient would live longer } \\
\text { following living donor transplantation } \\
\text { Themes: risk perception, lack of knowledge }\end{array}$ \\
\hline$\overline{6}$ & Rodrigue et al & $\begin{array}{l}\text { Patients' willingness to talk to others } \\
\text { about living kidney donation } \\
\text { DOI: } 10.7182 / \text { ptrt.18.t0jp08439772t722 }\end{array}$ & s2008 & USA & Questionnaires & $\begin{array}{l}\text { People with } \\
\text { AKD and on the } \\
\text { waiting list. }\end{array}$ & $\begin{array}{l}\text { h51\% Caucasians and } 49 \% \\
\text { eAfrican Americans }\end{array}$ & $\% 132$ & $\begin{array}{l}\text { White race, more education, less concern about living donor } \\
\text { kidney transplantation, and poorer perceived health are } \\
\text { associated with greater willingness to talk to others about living } \\
\text { kidney donation, } \\
\text { Themes: risk perception, Lack of knowledge }\end{array}$ \\
\hline$\overline{7}$ & Barnieh et al & $\begin{array}{l}\text { Barriers to living kidney donation } \\
\text { identified by eligible candidates with end } \\
\text { stage renal disease } \\
\text { DOI: } 10.1093 / \text { ndt/gfq } 388 \text {. }\end{array}$ & 2011 & Canada & Questionnaires & $\begin{array}{l}\text { People with } \\
\text { AKD who are } \\
\text { not on RRT }\end{array}$ & & 145 & $\begin{array}{l}\text { Not knowing how to ask someone for their kidney was the } \\
\text { most frequently reported barrier, identified by } 71 \% \text { of } \\
\text { respondents. Those that stated that living donation did not } \\
\text { pose significant long-term health risks to the donor were more } \\
\text { likely to pursue living kidney donation } \\
\text { Themes: Lack of Knowledge, risk perception, guilt }\end{array}$ \\
\hline 8 & Ismail et al & $\begin{array}{l}\text { Modifiable factors in access to living } \\
\text { donor kidney transplantation among } \\
\text { diverse populations }\end{array}$ & & Netherlands & Questionnaires & $\begin{array}{l}\text { People with } \\
\text { AKD referred } \\
\text { for transplant }\end{array}$ & $\begin{array}{l}\text { h51 \% of non-Western } \\
\text { dorigin and } 49 \% \text { of Western } \\
\text { torigin }\end{array}$ & & $\begin{array}{l}\text { Western patients scored higher in Knowledge and were more } \\
\text { willing to communicate to potential donors }\end{array}$ \\
\hline
\end{tabular}


Table (2): Interviews studies

\begin{tabular}{|c|c|c|c|c|c|c|c|c|c|}
\hline $\begin{array}{l}\text { Study } \\
\text { number }\end{array}$ & Author & Title & \begin{tabular}{|l|} 
Year \\
published
\end{tabular} & Location & Study design & Participants' characteristics & Ethnicity & $\begin{array}{l}\text { Sample } \\
\text { size }\end{array}$ & Important findings \\
\hline 14 & EJ Gordon & $\begin{array}{l}\text { "They don't have to suffer for me": why dialysis } \\
\text { patients refuse offers of living donor kidneys } \\
\text { DOI: } 10.1525 \text { maq.2001.15.2.245 }\end{array}$ & s2001 & USA & Interviews & People with AKD and on dialysis & $\begin{array}{l}\text { African Americans } 64 \% \text { European } \\
\text { Americans } 30 \% \text {. Other } 6 \%\end{array}$ & n79 & $\begin{array}{l}\text { Patients turn offers due to fear about donor's wellbeing and } \\
\text { compromising relations with donors } \\
\text { Themes: Risk perception }\end{array}$ \\
\hline$\overline{15}$ & Ismail et al & $\begin{array}{l}\text { Psychological barriers for living kidney } \\
\text { donation: how to inform the potential donors } \\
\text { DOl:10.1097/01.tp.0000284981.83557.dc }\end{array}$ & & Netherlands & Interviews & $\begin{array}{l}\text { People with AKD and on the waiting } \\
\text { list who didn't purse living kidney } \\
\text { donation (991) and their potential } \\
\text { donors (53) and a control group of } \\
\text { those identified a living donor and } \\
\text { started assessments for living donor } \\
\text { transplantation (53) and their donors } \\
\text { (51) }\end{array}$ & & 248 & $\begin{array}{l}\text { Volunteering was perceived as a condition for proceeding with the } \\
\text { donor-recipient relationship, sense of guilt if complications } \\
\text { happen to the donor following transplantation } \\
\text { Themes: Guilt }\end{array}$ \\
\hline$\overline{16}$ & Boulware et al & $\begin{array}{l}\text { Identifying and addressing barriers to African } \\
\text { American and non-African American families' } \\
\text { discussions about pre-emptive living related } \\
\text { kidney transplantation. } \\
\text { DOl: } 10.7182 / \text { prtt.21.2.2001j18x785u10hg }\end{array}$ & & USA & $\begin{array}{l}\text { Group } \\
\text { interviews }\end{array}$ & People with AKD and their families & $\begin{array}{l}2 \text { African American groups and } 2 \text { Non-1 } \\
\text { African American groups) } 0 \% \text { African } \\
\text { Americans }\end{array}$ & $\begin{array}{l}16 \\
-16\end{array}$ & $\begin{array}{l}\text { Both groups of patients were concerned about how to initiate } \\
\text { discussions, worried about burdening family members and } \\
\text { inducing guilt. } \\
\text { Themes: lack of Knowledge, guilt }\end{array}$ \\
\hline 17 & Ismail et al & $\begin{array}{l}\text { Religious attitudes towards living kidney } \\
\text { donation among Dutch renal patients } \\
\text { DOl: } 10.1007 / \text { s1 1019-011-9326-z }\end{array}$ & 2011 & Netherlands & $\begin{array}{l}\text { Interviews/focus } \\
\text { groups }\end{array}$ & $\begin{array}{l}\text { is People with AKD and on the waiting } \\
\text { list with no living donors }\end{array}$ & $\begin{array}{l}\text { gNon-European ethnic groups in } 5 \\
\text { Netherlands: Turkish, Moroccan, } \\
\text { Surinamese, Dutch Antillean and Cape } \\
\text { Verdean }\end{array}$ & n50 & $\begin{array}{l}\text { Religion was not recognised as an obstacle for living donation } \\
\text { however there are uncertainties and a lack of awareness about the } \\
\text { position of religion regarding living organ donation within } \\
\text { communities } \\
\text { Theme: Religion }\end{array}$ \\
\hline$\overline{18}$ & Davies et al & $\begin{array}{l}\text { Inter- and Intrapersonal Barriers to Living } \\
\text { Donor Kidney Transplant among Black } \\
\text { Recipients and Donors } \\
\text { DOl: } 10.1007 / 540615-016-0270-8\end{array}$ & & USA & Interviews & Donors and recipients & Black African Americans & 20 & $\begin{array}{l}\text { Avoidance of severity of End stage kidney disease and desire to } \\
\text { maintain health privacy } \\
\text { Themes: Risk perception. "Culture of salience" }\end{array}$ \\
\hline 19 & $\begin{array}{l}\text { M A Jones, } \\
\text { Cornwall }\end{array}$ & $\begin{array}{l}\text { J"It's hard to ask": examining the factors } \\
\text { influencing decision-making among end-stage } \\
\text { renal disease patients considering approaching } \\
\text { family and friends for a kidney } \\
\text { PMID: } 29723174\end{array}$ & & New Zealand & Interviews & $\begin{array}{l}\text { People with AKD and on the waiting } \\
\text { list with no living donors and those } \\
\text { with living donors undergoing work } \\
\text { up. }\end{array}$ & $\begin{array}{l}\text { gSix participants identified as Mäori, } \\
\text { ethree identified as Mäori/New Zealand } \\
\text { kEuropean, five identified as New } \\
\text { Zealand European, and one identifified } \\
\text { as Other European }\end{array}$ & & $\begin{array}{l}\text { Reciprocity, inability to accept responsibility, worries abou } \\
\text { donor's health. Health literacy } \\
\text { Themes: Culture, lack of knowledge, } \\
\text { Risk perception }\end{array}$ \\
\hline 20 & Sandal et al & $\begin{array}{l}\text { Health Professional-Identified Barriers to Living } \\
\text { Donor Kidney Transplantation: A Qualitative } \\
\text { Study } \\
\text { DOl: } 10.1177 / 2054358119828389\end{array}$ & & Canada & Interviews & $\begin{array}{l}\text { Transplant coordinators, dialysis } \\
\text { nurses, and general nephrologists }\end{array}$ & Un-specified & 16 & $\begin{array}{l}\text { Health care professionals reported better ability to convince } \\
\text { younger patients to resort to living donation and that patients fear } \\
\text { approaching potential donors and don't know how to formulate } \\
\text { their donation request } \\
\text { Themes: lack of knowledge }\end{array}$ \\
\hline
\end{tabular}

Table (3): Focus groups studies

\begin{tabular}{|c|c|c|c|c|c|c|c|c|c|}
\hline Study number & Author & Tritle/ DOI & $\begin{array}{l}\text { Year } \\
\text { publishe } \\
\text { d }\end{array}$ & Location & Study design & $\begin{array}{l}\text { Participants' } \\
\text { characteristics }\end{array}$ & Ethnicity & $\begin{array}{l}\text { Sample } \\
\text { size }\end{array}$ & Important findings \\
\hline 21 & Shilling et al & $\begin{array}{l}\text { Healthcare professionals } \\
\text { perceptions of the barriers to } \\
\text { living donor kidney } \\
\text { transplantation among African } \\
\text { Americans } \\
\text { DOI: } \\
\text { 10.1177/2054358119828389 } \\
\end{array}$ & & USA & Focus groups & $\begin{array}{l}\text { Physicians, transplant } \\
\text { coordinators, } \\
\text { pharmacists and a data } \\
\text { coordinator }\end{array}$ & $\begin{array}{l}\text { thealth professional's1 } \\
\text { ethnicity unspecified, } \\
\text { astudy targeted African } \\
\text { Americans }\end{array}$ & & $\begin{array}{l}\text { Main barriers identified were pre-existing medical conditions, financial } \\
\text { concerns, reluctance to ask family members and/or friends, distrust of the } \\
\text { medical community, fear of surgery, and lack of awareness about living donor } \\
\text { kidney transplantation } \\
\text { Themes; Lack of Knowledge, medical mistrust, fear of financial burden, Risk } \\
\text { perception }\end{array}$ \\
\hline$\overline{22}$ & $\begin{array}{l}\text { Waterman e } \\
\text { al }\end{array}$ & 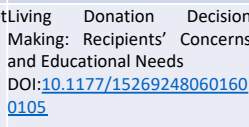 & & USA & Focus groups & $\begin{array}{l}\text { Recipients (33), donors } \\
\text { (4) and their families (3) }\end{array}$ & $\begin{array}{l}\text { sCaucasians } 73 \% \text { African } 4 \\
\text { Americans } 24 \%\end{array}$ & 40 & $\begin{array}{l}\text { Recipient might not pursue living kidney donation because they might feel guilty } \\
\text { /indebted to the donor / causing harm } \\
\text { Themes: Risk perception, guilt }\end{array}$ \\
\hline$\overline{23}$ & Alvaro et al & $\begin{array}{l}\text { Living kidney donation among } \\
\text { Hispanics: a qualitative } \\
\text { examination of barriers and } \\
\text { opportunities. } \\
\text { DOI: } \\
\underline{10.1177 / 15269248080180040} \\
\underline{6}\end{array}$ & & USA & Focus groups & $\begin{array}{l}\text { All participants were } \\
\text { aged Hispanics } 16 \text { or } \\
\text { above }\end{array}$ & eHispanics & 52 & $\begin{array}{l}\text { Lack of information was identified as the main barrier } \\
\text { Themes: Lack of Knowledge }\end{array}$ \\
\hline$\overline{24}$ & $\begin{array}{l}\text { E J Gordon e } \\
\text { al }\end{array}$ & $\begin{array}{l}\text { Hispanic/Latino concerns about } \\
\text { living kidney donation: a focus } \\
\text { group study } \\
\text { DOI: } 10.7182 / \text { pit2014946 }\end{array}$ & & USA & Focus groups & $\begin{array}{l}\text { kidney transplant } \\
\text { recipients, living kidney } \\
\text { donors, People with } \\
\text { AKD, and the general } \\
\text { Hispanic public. }\end{array}$ & $\begin{array}{l}\text { Participants were from7 } \\
\text { yHispanic origin and } \\
\text { nclassified to Mexican, } \\
\text { IPuerto Rican, Central or } \\
\text { South American Other } \\
\text { Latino }\end{array}$ & & $\begin{array}{l}\text { Knowledge deficits about LDKT and expectations of shorter life expectancy of } \\
\text { donors following transplantation, fear of becoming unable to work, losing one's } \\
\text { job, or being unable to pay household bills while recovering concerns with } \\
\text { immigrant logistics } \\
\text { Themes: Lack of knowledge, fear of financial burden, risk perception }\end{array}$ \\
\hline$\overline{25}$ & Seigel et al & $\begin{array}{l}\text { Barriers to living donation } \\
\text { among low-resource Hispanics } \\
\text { DOI: } \\
\text { 10.1177/1049732314546869 }\end{array}$ & 2014 & USA & Focus groups & $\begin{array}{l}\text { Hispanic patients with } \\
\text { chronic kidney disease }\end{array}$ & Hispanics & 28 & $\begin{array}{l}\text { Lack of knowledge about LDKT process, fear that donors won't be able to } \\
\text { support their families after transplantation and lack of social support because of } \\
\text { illness } \\
\text { Themes: Lack of knowledge, fear of financial burden }\end{array}$ \\
\hline
\end{tabular}




\section{Barriers from patients' perspective}

A number of barriers were identified in these studies and described below along with corresponding study number (SN) with link in the Tables 1,2,3.

\section{Lack of Knowledge}

Various aspects of knowledge are highlighted as playing a role in recipients' decision making including knowledge about renal disease, LDKT process and how and when to initiate the discussions with potential donors (SN 4,5,6,7,8,9,11,12,16,19,20,21,23,24,25). Ethnic variability was reported in the degree of knowledge as people from some BAME backgrounds were found to score lower in knowledge about the living donation process, donor eligibility and financial consequences following donation. This lack of knowledge was associated with a lower likelihood of engaging in the LDKT process and identifying a living donor (SN 4,8).

\section{Risk perception}

The recipient's perception about their own health and donor's risks during and after the transplantation process has been linked to the levels of communication and willingness to introduce the concept of LDKT to potential donors across all ethnic groups

$1,2,3,4,5,6,7,10,11,14,18,19,21,22,24)$.

(SN Americans are more likely to deny the need for transplant, perceive benefits of staying on dialysis (SN $6)$ and have more concerns about the surgery (SN 4).

\section{Religion and culture}

Despite the fact that no religion appears to explicitly forbid living or deceased organ donation ${ }^{(10)}$, recipients from non-Christian religions were found to have a lower likelihood for pursuing LDKT ${ }^{(7)}$. Ismail et al (SN 17) explored different religious attitudes towards living kidney donation in patients on the transplant waiting list with participants identifying themselves as Muslims, Christians, Buddhists and Atheists (38\%, 50\%, $8 \%$ and $6 \%$ respectively). Religion was not reported as a barrier to living kidney donation and the majority of the study participants had a positive attitude towards LDKT, motivated by their religious values to help others. Some people from Muslim communities had concerns around body preservation and disfigurement resulting from organ donation and transplantation. The study also highlighted uncertainties about the opinion of their own religion towards kidney donation with possible religious misinterpretations linked to community culture. Wong et al (SN 13) also reported that religion was not perceived as a barrier to living donation, however some participants who identified as Black and Christian reported that their potential donors refrained from donation as their religion wouldn't allow them. None of those patients reported sharing the same belief as their donors. None of the studies explored views and possible reservations about living kidney donation from people within other major religious groups (eg Hinduism or Sikhism).

Various cultural behaviours were identified as potential barriers to LKD decision making. A "culture of silence" about renal disease was reported in families from (BAME) communities in the United Kingdom, restricting the patient's access to the large pool of potential donors (SN 13). The culture of reciprocity is prevalent in the Maori and Pacific communities and was reported to play a role in the decision making in LDKT: some patients refrained from asking for a kidney from a family member or loved one as it was considered too big as gift that couldn't be paid back (SN 19). No similar cultural attitudes were reported in patients from White ethnic background.

\section{Guilt}

Guilt associated with requiring and asking for a kidney, has been reported as discouraging people from engaging in transplant discussions with their potential donors. Furthermore, recipients might feel guilty and indebted to the donor and refrain from accepting a kidney offer due to a concern that a family member may need the organ in future $(S N 4,7,10,15,16,22)$.

\section{Fear of financial burden}

People with AKD including those from a BAME background may have concerns about influencing financial hardship on potential donors by causing someone to lose their job and jeopardising their ability to look after their families (SN 10,12,13,21,24,25). However, those concerns are difficult to compare as health care services and social benefits are funded differently between countries. People from BAME communities in the United Kingdom are more likely than to express financial concerns preventing family members from accessing kidney donation compared to people from a white ethnicity (SN 13).

\section{Medical mistrust}

Medical mistrust is an important factor affecting African Americans engagement with health services (12). African American patients with advanced kidney disease were reported to believe that the health system treats rich people from a White ethnic background in a better way compared to others (SN 4,21). 


\section{Health Professionals' Perspective}

Only two studies explored health professionals' experiences in decision making around LKDT. Health professional views about barriers to African Americans seeking LKDT included: knowledge about LDKT, higher risk perception about the surgery, financial concerns and reluctance to engage in discussions about donation with potential donors and medical mistrust (SN 21).

Health professionals from Canada reported a greater confidence in their ability to convince younger patients to choose living donation, a finding that supports previous studies exploring factors associated with pursuing $\mathrm{LDKT}^{(7)}$. They also reported that patients fear approaching potential donors as they may not know how to formulate their donation request (SN 20).

\section{Discussion and conclusion}

Decision making about living kidney donation is a complex process, and health professionals rely on people with AKD to initiate conversations with potential donors. This review has summarised some of the key barriers that people face when discussing potential LKDT with their family and friends. Most of the themes identified in this review were seen across all ethnic groups, however some variation was noted in the domains of knowledge, risk perception and fear of imposing a financial burden. Religious and cultural reservations as well as mistrust of the medical establishment were only identified in people from BAME communities in the Western countries.

Some of these barriers are modifiable and can be improved by targeted interventions, for example, improving knowledge and framing risk information in ways that are known to improve understanding. There was little focus on the views of individuals from diverse ethnic/religious groups in the UK particularly those from certain Muslims, Hindus and Sikhs. Despite kidney health professionals playing a key role in initiating conversations about LKD, few studies have explored their views on encouraging people to discuss donation with their friends and families.

Patient decision aids are interventions to help people make informed healthcare decisions. Unlike patient information leaflets which are aimed at improving knowledge about diseases and treatment options, patient decision aids provide evidence-based information about different aspects of each treatment option and their consequences without bias, and take into account people's values and preferences, encouraging people to make trade-offs about what is important to them in order to reach a decision $(13,14,15,16,17)$

\section{Limitations}

A scoping review method is not as comprehensive as a systematic review, may be more prone to bias and the inadvertent omission of key pieces of evidence. However adopting this method provides a screening measure to inform future research. And in this case was devised to assist in the development of a culturally sensitive multi-dimensional patient decision aid that utilises the best available evidence to facilitate conversations between the patients with kidney disease and their potential donors with particular focus on the South Asian community which constitutes the largest ethnic minority in the UK ${ }^{(7)}$.

\section{Acknowledgement:}

We would like to thank Kidney Research Yorkshire charity

(https://www.kidneyresearchyorkshire.org.uk/) for funding this study

References:

1) Terasaki PI et al: High survival rates of kidney transplants from spousal and living unrelated donors. $N$ Engl J Med. 1995 Aug 10; 333(6):333-6. DOI:10.1056/NEJM199508103330601.

2) Laupacis A et al: A study of the quality of life and cost-utility of renal transplantation. Kidney Int. 1996 Jul; 50(1):235-42. DOI: 10.1038/ki.1996.307.

3) Cecka JM: Living donor transplants. Clin Transpl.1995;363-77. PMID: 8794280.

4) NHS blood and transplant annual activity report kidney report 2019-2020.

5) UK census 2011 https://www.ons.gov.uk/census/2011census

6)Raleigh VS: Diabetes and hypertension in Britain's ethnic minorities: implications for the future of renal services, BMJ- 1997 Jan 18;314(7075):209-13. DOI: 10.1136/bmj.314.7075.209.

7) Bailey PK et al: Beliefs of UK Transplant Recipients about Living Kidney Donation and Transplantation: Findings from a Multicentre Questionnaire-Based Case-Control Study, J Clin Med. 2020 Jan; 9(1): 31. DOI:10.3390/jcm9010031.

8) Wu et al: Barriers to living donor kidney transplantation in the United Kingdom. Nephrol dial transplant, 2017 May 1;32(5):890-900. DOI: 10.1093/ndt/gfx036.

9) Peracha et al: Gender Disparity in Living-Donor Kidney Transplant Among Minority Ethnic Groups, Exp 
Clin Transplant, 2016 Apr;14(2):139-45. PMID: 27015531.

10) Khangura $S$ et al: Evidence summaries: the evolution of a rapid review approach. Syst Rev. 2012; 1:10. DOI: 10.1136/ebm.6.4.100.

11) Bruzzone P: Religious aspects of organ donation, Transplant Proc, 2008 May;40(4):1064-7. DOI: 10.1016/j.transproceed.2008.03.049.

12) Powell $W$ et al: Medical Mistrust, Racism, and Delays in Preventive Health Screening Among African American Men, Av Med, Apr-Jun 2019;45(2):102-117. DOI: 10.1080/08964289.2019.1585327.

13) Stacey $D$ et al: Decision aids for people facing health treatment or screening decisions. Cochrane Database of Systematic Reviews. 2014;(1) Art. No.: CD001431.

DOI: 10.1002/14651858.CD001431.pub5.

14) Bekker $\mathrm{H}$ et al: Informed decision making: an annotated bibliography and systematic review. Health Technol Assess Winchester, UK 1999; 3:1-156. DOI: 10.3310/hta3010.

15) O'Connor et al: Edwards E. Chapter 14: The role of decision aids in promoting evidence-based patient choice. In: Edwards A, Elwyn G, eds. Evidence-based patient choice: inevitable of impossible. Oxford, UK: Oxford University Press, 2001(pages 220-242). DOI: 10.1136/ebm.6.4.100.

16)Winterbottom et al: Evaluating the quality of patient leaflets about renal replacement therapy across UK renal units, Nephrology Dialysis Transplantation, Volume 22, Issue 8, August 2007, Pages 2291-2296. DOI:10.1093/ndt/gfm095.

17)Winterbottom et al: Patient Acceptability of the Yorkshire Dialysis Decision Aid (YoDDA) Booklet: A Prospective Non-Randomized Comparison Study Across 6 Predialysis Services. Perit Dial Int, Jul-Aug 2016;36(4):374-81. DOI: 10.3747/pdi.2014.00274.

\section{Conflict of interest}

The authors have no conflict of interest to declare. The corresponding author declares that this is an original work which is not submitted/ accepted/ being considered by another journal/ publisher at the current time 